\title{
SRI LANKA'S
}

\section{MIGRANT LABOR REMITTANCES:}

\author{
Enhancing the Quality and Outreach of \\ the Rural Remittance Infrastructure
}

\author{
Esperanza Lasagabaster \\ Samuel Munzele Maimbo \\ Sriyani Hulugalle
}

World Bank Policy Research Working Paper 3789, December 2005

The Policy Research Working Paper Series disseminates the findings of work in progress to encourage the exchange of ideas about development issues. An objective of the series is to get the findings out quickly, even if the presentations are less than fully polished. The papers carry the names of the authors and should be cited accordingly. The findings, interpretations, and conclusions expressed in this paper are entirely those of the authors. They do not necessarily represent the view of the World Bank, its Executive Directors, or the countries they represent. Policy Research Working Papers are available online at http://econ.worldbank.org.

Esperanza Lasagabaster (elasagabaster@worldbank.org) is Senior Financial Economist, Samuel Munzele Maimbo (smaimbo@worldbank.org) is Senior Financial Sector Specialist and Sriyani Hulugalle (shulugalle@worldbank.org) is a Senior Economist in the Finance and Private Sector Unit, South Asia Region of the World Bank. The authors gratefully acknowledge comments from Anjali Kumar, Mona Sur, Dina Umali-Deininger, Simon C. Bell, Alawode Abayomi, Haans Boon, Peter Harold, Ismail Radwan, Ole Andreason, and Ranee Jayamaha for their valuable comments. The authors wish to record the excellent administrative support provided by K. Nalin Perera, Maria Marjorie Espiritu, Sakm Abdul Hye, and Malathi Ratnayake. The paper draws on a larger Economic and Sector Work study on remittances, which was funded by the South Asia Region Vice Presidency and South Asia Finance and Private Sector Development Unit of the World Bank. 


\section{TABLE OF CONTENTS}

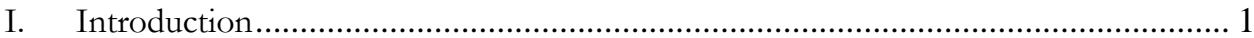

II. Formal and Informal Infrastructure for Remittances......................................... 4

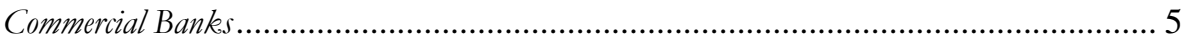

Money Transfer Businesses .......................................................................................... 8

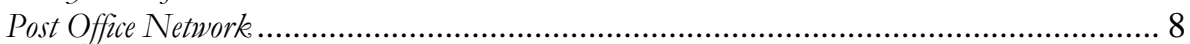

Informal Remittance Systems ......................................................................... 9

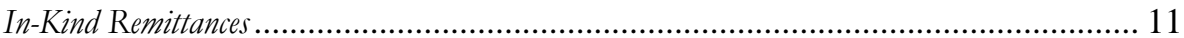

III. Public and Private Sector Options for Enhancing the Use of Formal Remittance

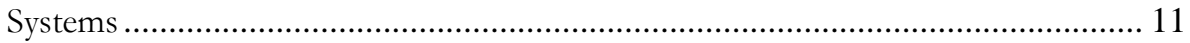

Greater Investment into Remittance Technology ............................................................. 12

Sharing Electronic Payments Systems Platforms ...................................................... 14

Creating Payments Systems Linkages with Non-Bank Financial Institutions ....................... 17

Negotiating Bilateral Financial Initiatives ................................................................. 18

Financial Education and Consumer Protection ........................................................... 18

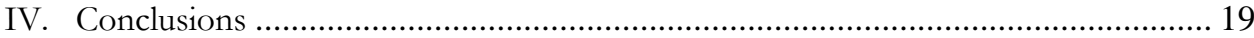

V. Annex 1 Summary of Migrant Labor remittances in the South Asia region.......... 21

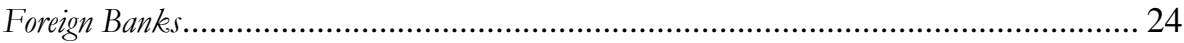

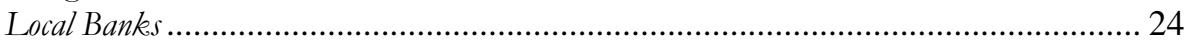

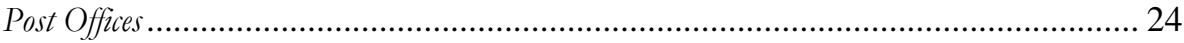

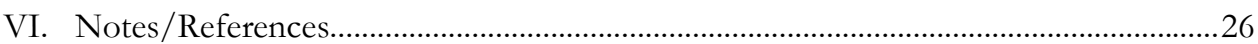




\section{ENHANCING THE OUTREACH AND QUALITY OF THE RURAL REMITTANCE INFRASTRUCTURE}

\section{Introduction}

Migrant labor remittances into Sri Lanka are significant and rising. At the end of 2004, recorded remittances had increased to US\$1.3 billion (Table 1). Together with Bangladesh (US $\$ 3.4$ billion), India (US\$23.0 billion), and Pakistan (US\$2 billion), Sri Lanka was among the 20 largest recipients of remittances, collectively making the South Asia region the second largest regional recipient of remittances in the world after Latin America and the Caribbean.

Table 1 Estimates of Workers' Remittances Channeled through the Formal Financial Infrastructure

(US\$ Billion)

\begin{tabular}{lrrrrrrr} 
& \multicolumn{1}{c}{1999} & 2000 & 2001 & 2002 & 2003 & 2004 & $\begin{array}{c}2003 \\
\text { (per capita US\$) }\end{array}$ \\
Total & 10 & 16.0 & 15.9 & 21.4 & 25.9 & 31.9 & \\
$\quad$ Bangladesh & 1.8 & 2.0 & 2.1 & 2.8 & 3.2 & 3.4 & 23.2 \\
India & 11.1 & 11.7 & 11.1 & 13.7 & 17.4 & 23.0 & 15.8 \\
Pakistan & 0.1 & 1.1 & 1.5 & 3.6 & 0 & 2 & 27.0 \\
Sri Lanka & 1.0 & 1.2 & 1.2 & 1.3 & 1.3 & 1.3 & 67.7 \\
Sri Lanka: as percent GDP & 6.8 & 7.1 & 7.5 & 7.9 & 7.1 & 7.1 &
\end{tabular}

Source: World Bank (2005)

Significantly, remittances are larger ${ }^{1}$ and more stable ${ }^{2}$ than foreign direct investment (FDI), and on a per capita basis, workers' remittances to Sri Lanka are the highest in South Asia (Figure 1). In recent times, remittances to Sri Lanka have exceeded FDI inflows by 2 to 3 times; more than doubled net receipts of foreign assistance; and reached close to 25 percent of export earnings, second only to the garment industry and ahead of tourism and tea -- the island's traditional export industry. They account for 7 percent of gross domestic product. At the microeconomic level, about 10 percent of households are recipient of overseas and domestic remittances. Overseas and domestic remittances constitute as much as 20.7 percent and 9.1 percent, respectively, of total income of recipient households, according to the $2001 / 2002$ household survey. ${ }^{3}$ 
Figure 1 Sri Lanka: Formal Remittances Surpass FDI Inflows

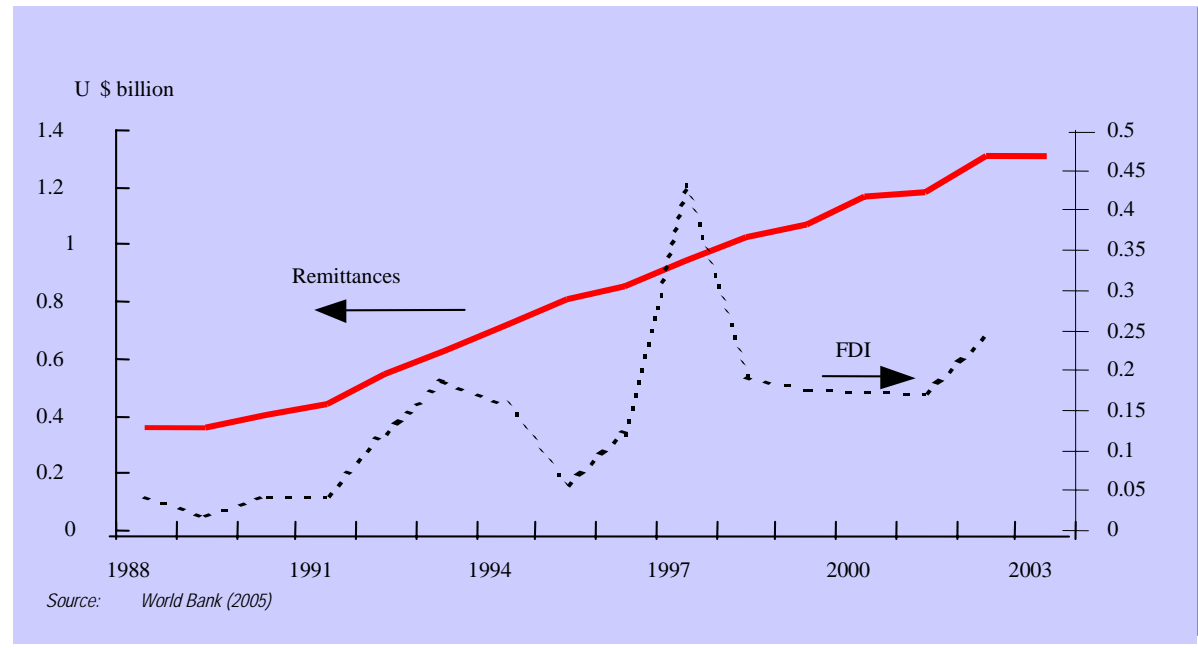

Remittance flows are set to continue increasing as unskilled workers continue to migrate to the Middle East (Annex 1). For the unskilled worker, temporary migration to the Middle East ${ }^{4}$ brings in earnings that are 8 times greater than what could be expected at home. ${ }^{5}$ The Sri Lanka Bureau of Foreign Employment (SLBFE) estimates that 49 percent and 21 percent of Sri Lankans departing to work overseas in 2003 were housemaids or unskilled, respectively (Figure 2). Notably, nearly 70 percent of Sri Lankan temporary migrants are female (Annex 1); most of them working as housemaids. Just over one percent of all migrant workers are classified as skilled.

Figure 2 Sri Lanka. Skill Level of Departing Migrant Workers (2003)

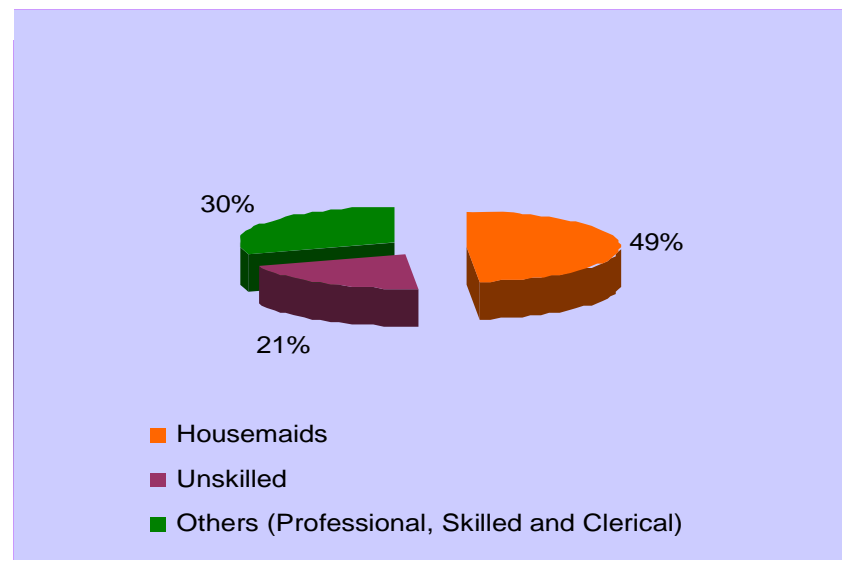

Source: SLBFE 
The Sri Lankan household survey of 2001/2002 indicates that about 28 percent of remittance recipient households stand within the top income quintile and around 27 percent stand within the lowest two income quintiles. These ratios, however, change considerably in the pre-remittance scenario. When remittances are deducted from total household expenditure, nearly 45 percent of recipient households stand within the lowest two income quintiles. Although information on how Sri Lankan recipient households use remittances is not yet conclusive, the above findings suggest that remittances can have an important impact on recipient households. A broader study by the International Monetary Fund (IMF) on remittances concluded that "remittances can help improve a country's development prospects, maintain macroeconomic stability, mitigate the impact of adverse shocks, and reduce poverty" . Remittances allow families to maintain or increase expenditure on basic consumption, housing, education, and small-business formation; they can also promote financial development in cash-based developing economies (IMF 2005). Speaking to the role of the financial sector in facilitating remittances, the IMF study also concluded that long-run output growth resulting from additional investments in physical and human capital financed by remittances might be especially likely "where a well-developed financial system and institutions allow remittances to be effectively intermediated and efficiently used" (IMF 2005).

The Sri Lankan government ${ }^{7}$ like other developing country governments has recognized the importance of remittances and introduced incentives to facilitate foreign employment-including pre-migration facilities and services, identification of employment opportunities, training, and pre-departure loan schemes (Annex 1). It is also debating the capacity of formal financial institutions to facilitate migration policies and the challenge of enhancing the quality and outreach of the remittance infrastructure, especially in the face of an active informal remittance sector. To the extent remittances are transferred through formal financial institutions, the government's balance of payments benefits from the increased foreign-exchange reserves. In addition, the anonymity that is possible through informal remittance systems renders remittance systems highly vulnerable to abuse and illegal activities. Like other governments in remittance recipient countries, the Sri Lankan authorities are interested in having as much of the remittance flows go through formal conduits.

This paper reviews the key issues affecting the formal financial infrastructure for remittances in Sri Lanka. Section 2 details how the combined infrastructure of banking institutions, postal system, and microfinance institutions provides a dense network for remittances flows. It also shows, however, that the formal infrastructure's potential is not being maximized. The country remains largely cash dominated, and rural areas, where the greatest share of remittances flow, enjoy less access to formal remittance products (Figure 3). 
Figure 3 Sri Lanka. Remittance Flows to Urban Rural and Estate Households (percent of total)

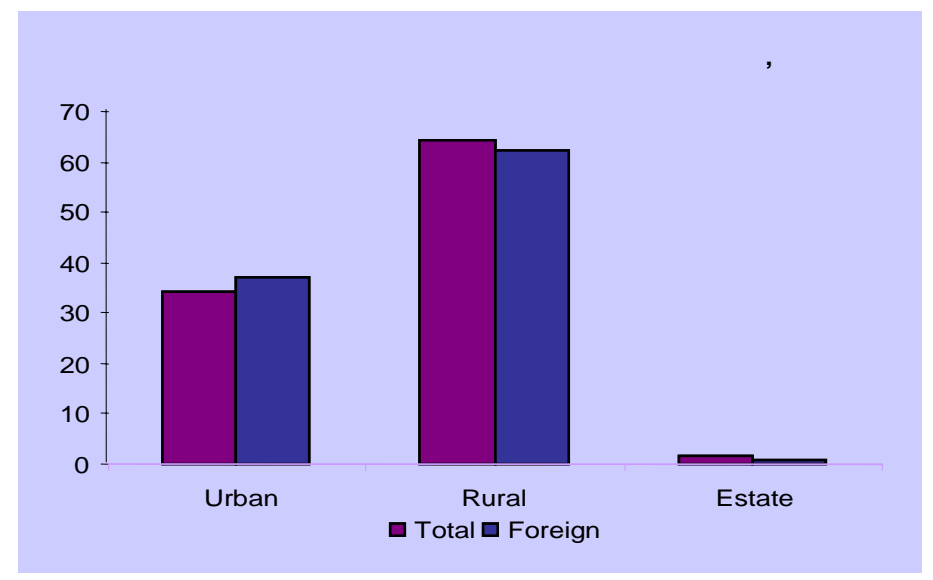

Section 3 makes suggestions to strengthen the formal remittances' infrastructure ${ }^{8}$ to enable it to compete with informal service providers, and Section 4 summarizes policy recommendations.

\section{Formal and Informal Infrastructure for Remittances}

Overall, Sri Lanka has an impressive density of institutions providing financial services (state and commercial banks, postal network, and microfinance institutions), which offer a good basic infrastructure for remittances flows.

Under the Exchange Control Act, foreign exchange transactions are permitted only through licensed commercial banks appointed as fullfledged authorized dealers, unless any other person is appointed by the Central Bank of Sri Lanka (CBSL) as a restricted dealer. Accordingly, both inward and outward remittances from and to Sri Lanka are presently effected through 22 licensed commercial banks (Table 2).

Table 2 Remittances by Licensed Commercial Banks (million Rupees)

\begin{tabular}{lrrrr}
\hline \multicolumn{1}{c}{ Institution } & 2002 & 2003 & 2004 & $\begin{array}{c}\text { 2004 } \\
\text { (\% of total) }\end{array}$ \\
\hline Bank of Ceylon & 741.8 & 772.0 & 881.4 & 56.4 \\
People's Bank & 183.3 & 208.9 & 232.7 & 19 \\
Seylan Bank & 102.5 & 129.0 & 147.5 & 9.4 \\
Hatton National Bank & 42.7 & 57.5 & 81.6 & 5.2 \\
Comercial Bank & 63.7 & 79.6 & 93.4 & 6.0 \\
Sampath Bank & 58.8 & 75.4 & 76.1 & 9 \\
Others & 92 & 91.6 & 51.2 & 3.3 \\
Total & $\mathbf{1 , 2 8 7 . 0}$ & $\mathbf{1 , 4 1 0}$ & $\mathbf{1 , 5 6 3 . 9}$ & $\mathbf{1 0 0 . 0}$ \\
\hline Source: Hettiarachi(2005) & & & &
\end{tabular}


In addition to authorized dealers, Sri Lanka Post (SLP), the National Savings Bank (NSB), which is a licensed specialized bank, and one private company, MMBL Money Transfer Ltd. (MMBL), which is a subsidiary of a Merchant Bank in Sri Lanka, are permitted to engage in money transfers as restricted dealers. Of these, NSB and MMBL are permitted only to engage in inward money transfers. Although provisions under the Exchange Control Act prohibit any other entity to participate in the remittance business without the permission from the central bank, some informal remitters are in operation. The identification of these informal dealers becomes difficult as their operators and localities are unknown and they hardly keep readily accessible records of their transactions (Hettiarachi, 2005). Estimates based on a recent World Bank study (2005a) suggest that the share of private remittances channeled through informal dealers could have been close to 45 percent in the mid-1990s.

The potential of the formal remittance infrastructure is not being maximized. The country remains largely cash dominated. Although the banks report a relative good (checking) account-to-per-capita ratio of about 1:6, the usage appears low, with only 4 cashless payments transactions per capita, or approximately 25 per account per year. On the other hand, many Sri Lankans keep large amounts of cash at hand. An average Rs. 5,000 per capita were in circulation with individuals in mid-2004 (Boon 2005). This suggests that access to basic payments services is in practice difficult. There is close to one branch per 14,000 inhabitants, but this ratio is inadequate to serve the nation given that the financial sector is predominantly cash-based and paper-based. ${ }^{9}$ Lessons from other countries show that this ratio should at least be 1:6,000 and ideally better than 1:3,000, as is the case in most industrialized economies (Boon 2005).

The remainder of this section examines the state of the formal and informal infrastructure for remittances in Sri Lanka. As is the case in other regions, the financial remittance market includes three principal actors-commercial banks, money transfer businesses, and informal money transfer agents. Slowly, other actors-such as the post office and microfinance institutions - have begun exploring opportunities in the remittance industry but their participation is still in its infancy.

\section{Commercial Banks}

State commercial banks, especially Bank of Ceylon, have long dominated the official remittance business, in part because of their large branch networks. In 2004, their network comprised 618 branches compared to 1734 for the entire banking system and together they channeled close to 70 percent of private remittances. ${ }^{10}$ Table 3 summarizes the contribution of the main commercial banks to private remittances during the last 3 years.

The retail product range of the commercial banks is fairly broad, ranging from checking accounts, deposits, credit, insurance, and securities. For migrants and their relatives, banks offer check products as well as electronic and internet based products. In a recent survey of financial institutions, Hettiarachi (2005) found the following were the most widely used instruments for transferring money: (i) Telegraphic Transfers based on SWIFT messages; (ii) drafts/checks drawn on banks; ${ }^{11}$ and (iii) international money orders issued by banks and post offices. 


\begin{tabular}{lrr}
\hline \multicolumn{1}{c}{ Type } & 2002 & \multicolumn{1}{c}{$\mathbf{2 0 0 3}$} \\
\hline Ordinary money orders & $7,795.9$ & $9,437.6$ \\
Telegraphic money orders & 356.9 & 446.7 \\
Fax money orders & 652.2 & $1,147.2$ \\
International money orders & 135.9 & 382.2 \\
\hline
\end{tabular}

Source: Central Bank of Sri Lanka (2004)

Increasingly, private commercial banks have also started eyeing the remittances market. Sensing a growing market for remittances in Sri Lanka, several banks have introduced remittance services and started aggressive marketing programs. Some banks offer a variety of products to migrants including insurance and pre-departure loans at concessional rates to be repaid from remittance proceeds. The size of the loan is determined by the level of income offered by the prospective employer and the duration of employment. Some migrants use the loans to pay their employment agency fees, passage, and settling-in costs. Box 1 below provides examples of the main products offered by commercial banks to migrants, including foreign currency accounts, insurance, accounts for minors, loan facilities, and educational programs. ${ }^{12}$

\section{Box 1 Financial Products and Services Offered to Migrants by Commercial Banks}

- Foreign currency accounts: In order to induce inward remittances, the CBSL has permitted non resident workers to open and maintain foreign currency accounts with authorized dealers. These accounts are known as "Non Resident Foreign Currency Accounts (NRFCs)". If the account is to be maintained by a beneficiary in Sri Lanka who is a resident, the proceeds of remittance received by him are permitted to be retained in an account titled "Resident Foreign Currency Account (RFCA)". Funds in both NRFCA and RFCA can be freely used for any purpose in foreign exchange (in the case of resident other than for acquisition of any real and financial assets abroad) and are free from income tax. These accounts offer competitive interest rates ranging from 1-2 percent over LIBOR.

- Insurance: Commercial banks arrange life insurance covers for migrant workers depositing money brought into the country the credit of a foreign currency account above certain threshold.

- Minors' accounts: Migrant workers are permitted to open accounts for minors in foreign currency in the name of their children in Sri Lanka to enable them to enjoy the benefits of retaining money in foreign currency for their future use.

- Loan facilities: A migrant worker who remits money either to a foreign currency account or a rupee account is in a position to raise loans from authorized dealers for housing and other purposes at a low interest rate.

- Pamphlets and advertisement. Advertisements published in printed and electronic media and various pamphlets issued by authorized dealers not only give publicity on facilities extended to migrant workers but also transparency with regard to the cost of remittances and exchange rates.

- Education program: SLFEB jointly with the Ministry of Education conduct seminars and other educational programs to educate migrant workers, regarding banking facilities available for remitting monies to Sri Lanka and as to how such facilities should be utilized to maximize benefits on their earnings. 
Foreign banks in Sri Lanka are newcomers to the remittance business and where they are involved, they have tended to focus on skilled migrants—doctors, accountants, lawyers, and other professionals—mainly account holders who have migrated. They are not known to offer competitively priced services to walk-in-clients. Their "reluctance" to participate in the sector is quite different from the experience in Latin America and Southeast Asia, where all banks are taking a serious interest in the remittances sector. The main reasons for their limited interest in the sector are discussed below:

- Transaction costs: The high minimum account balances required by commercial banks are a deterrent for lower-income migrants. People are reluctant to give up access to sizeable funds in order to maintain a bank account.

- Profitability of remittance business model: The remittances business has three direct sources of income-profit on the exchange rate, fees paid by the remitter and sometimes by the recipient, and the interest earned on remitted funds before they are paid out to the recipient. On all three accounts, the profits on remittances to the region have been falling. With the removal of exchange-rate controls in recent times, the margins have declined drastically. Competition between transfer agents has pushed down commissions and fees to US $\$ 1$ dollar or less, and pressure to make payments within 24 hours has minimized the potential for gains on cash float. Unless clients open bank accounts and banks are able to cross sell other more profitable products, remittances are not an attractive business proposition for foreign banks.

- Limited branch networks: Most foreign banks are concentrated in the capital cities. Their branch networks are designed for corporate clients and the more affluent individual clients. They do not have the rural outreach of the state banks and other local private banks.

- Anti-money laundering and counter financing of terrorism (AML/CFT) standards: Heightened international concerns over money laundering and terrorist financing have increased the pressure on international banks to adhere strictly to international AML/CFT standards. High volumes of individual money transfers, especially between non-account holders, make it difficult to comply with know-your-customer and suspicious activity reporting requirements. Reporting regulations could push the cost of doing business too high as remittance fees are dropping.

Most of the concerns listed above affect local private banks and nonbank financial institutions as well—and advances in technology have been used to address them. Technology is having a positive impact on the remittance market. As account holders in some of the more technologically advanced banks discover the benefits of ATM machines, debit cards, and credit cards, the volume of account-to-account money transfers is increasing. 


\section{Money Transfer Businesses}

Money transfer businesses play an important role in providing remittance services to Sri Lankan migrants. In the context of this chapter, money transfer businesses (MTBs) are financial service agents that accept cash, checks, other monetary instruments, or forms of "stored value" in one location and pay a corresponding sum in cash or another form to a beneficiary in another location by means of a communication, message, or transfer, or through a clearing network to which the MTB belongs.

In Sri Lanka, MTBs operate through banks, and there are initiatives to partner with other institutions. Only authorized foreign exchange dealers (i.e. commercial banks, the post office, and the National Savings Bank) are permitted to deal in foreign currency transfers. Exchange bureaus, credit unions, microfinance institutions are not.

The leading MTB in Sri Lanka is Western Union. With a 150-year history, Western Union is the global leader in money transfer services. It has more than 150,000 agent locations in 190 countries. Although estimates vary, it is commonly agreed that after banks, Western Union handles the largest share of remittances from the United States to South Asia. Western Union allows customers to send money using credit and debit cards through the company's Web sites, offices and agent locations, the telephone, or physical mail using a money order.

MTBs are increasingly taking advantage of the internet to expand their outreach and quality of their service delivery mechanisms. e-Exchange allows the remitter to transfer funds instantly to any part of Sri Lanka. The company asserts that its branch and ATM network throughout the country is electronically linked, thereby offering faster services. Senders can check to see whether funds have been received and can also review past transactions and print an account statement. For MTBs, the contribution of technology to the remittance business transfers is a welcome development. From a regulatory perspective, technology makes it easier to comply with know-your-customer requirements by automatically recording the identity of the remitter and the recipient. From the financial perspective, it allows a cross-selling of other financial products (e.g., credits cards and insurance products).

\section{Post Office Network}

Although the postal service has a long tradition in providing cross-border remittance instruments, its market share is minimal due to deficient and slow services. In 2004, the post dealt with remittances amounting to US\$ 8 million or less than one percent of the total market (Table 2). These primarily came from India and the United Kingdom. The remittance flows are settled through an account held at the Central Bank of Sri Lanka, which does the currency conversion. International postal money orders, which remain paper based, take up to 4 weeks to reach the beneficiary. Money orders can be cashed at any post office. The senders usually pay a value-based fee, in the range of $2-5$ percent of total value. The percentage of complaints and queries is higher than 5 percent. In comparison to remittances products offered by banks and money transfer agents, the paper-based postal money order compares poorly, except for its outreach. New initiatives are underway to improve the service. 
Table 4. Average Time Period to Remit Money to Sri Lanka (2005)

\begin{tabular}{lccc}
\hline \multicolumn{1}{c}{ Country } & TelegraphicTransfer & Draft/ Cheque & E-Remittance \\
\hline United Arab Emirates & 1-2 Days & $3^{\star}$-21 Days & $10-15$ Minutes \\
United States & 1-2 Days & $3^{*}$-21 Days & $10-15$ Minutes \\
European Union & 1-2 Days & $3^{*}$-21 Days & $10-15$ Minutes \\
\hline
\end{tabular}

*On local clearing

Source: Central Bank of Sri Lanka (2005)

Sri Lanka Post has struck an agreement with the United Emirates Posts, to exchange postal money orders electronically. The Emirates Post will help Sri Lanka Post with the installation of necessary software and training. This appears as a useful first step to improve the level of service with one of the key markets from where remittances originate. In 2004, Sri Lanka Post launched a tender for an agency for urgent money transfers and it was approached by representatives of firms such as MoneyGram and Western Union. A decision on the matter is in process.

\section{Informal Remittance Systems}

As is the case in most South Asian countries, informal remittances are commonplace, having long been used to facilitate trade between distant regions where conventional banking instruments are either absent or weak. World Bank (2005a) estimates that unrecorded remittances are highly volatile and could have reached as much as 45 percent of total private remittances in Sri Lanka in the mid-1990s (Figure 4). Broadly speaking, the growth of informal funds transfer systems has traditionally been negatively correlated with the level of development and liberalization of the formal financial sector. Informal systems are more likely to be found in jurisdictions where the formal financial sector is either virtually absent or not functioning — as is sometimes the case in internal regions in conflict-or does not provide a reliable, cost effective, and convenient mechanism for the transfer of funds. The attraction of informal operators is heightened by financial policies that include foreignexchange controls as was the case in Sri Lanka. Over time, the operational features of speed, low cost, ethnic and cultural convenience, versatility, and anonymity led to their use for various legal and illegitimate purposes. ${ }^{13}$ Many Sri Lankan banks identify informal remittances as their most challenging competitor. Although some banks have tried to tap into the informal markets, there are no examples of successful models. 
Figure 4 Sri Lanka Official and Unofficial Remittances (US\$ Million)

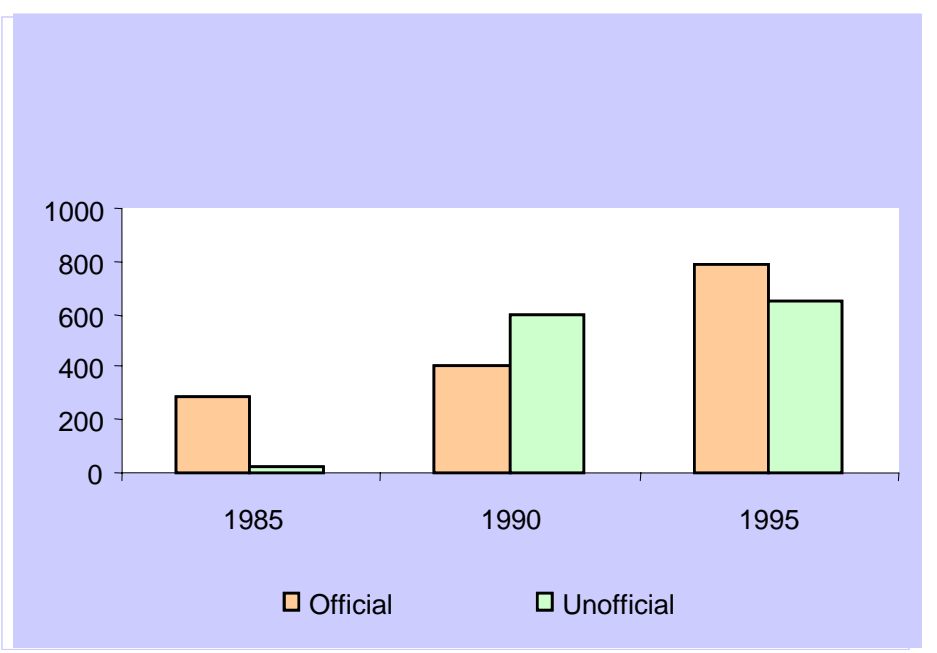

Source: World Bank (2005a)

In addition to cost and speed, informal remittance systems also fare more favorably for migrants, with respect to the formalities required to transfer money, reliability, and convenience. The informality of Hawala makes it attractive to many Sri Lankan migrants who find banks and other financial institutions uncomfortable to deal with. The lack of bureaucracy renders informal services accessible to less educated customers, many of whom live in rural areas where alternatives are not available in any case. Informal systems are also reliable. Trust and the cultural importance of one's reputation and good name perform an effective self-regulatory function. Disputes and errors are settled among informal service providers who assume the risk of a counterpart's default or law-enforcement actions.

The convenience of door-to-door service is appealing to all customers, especially in the regions where transportation is poor and to female migrants in remote and traditional regions, where they may not be allowed to leave the house. In some instances, as field surveys indicate, informal service providers visit the workplaces of expatriates to collect money for remittances. Private banks have opened branches in migrant-destination countries to assist Sri Lankan nationals remitting their earnings, and these branch offices have managed to attract a number of clients through personalized service. However, due to the constraints of work conditions, housemaids still prefer to use informal channels to remit their earnings. With the fluctuation of the dollar, many of these women are unaware that their informal contacts do not give them a fair exchange rate and that they are losing on the transaction. (See Malsiri et al. 1999.)

Areas of conflict are also more likely to be linked to informal methods of money transfers. The northern parts of Sri Lanka, for example, have limited formal financial services. Migrants from that region resort to the Hawala system and in-kind remittance services to make remittances. Informal remittance services are also attractive to the undocumented immigrants, who may not be permitted to have bank accounts or do business with formal institutions. This is said to be particularly important to Sri Lankan migrants based in Italy. 
Unfortunately, illegitimate use of the informal Hawala system may occur regardless of the level of development and convenience of the formal financial sector. While both the formal and informal sectors are vulnerable to abuse, the potential anonymity of the informal system makes it especially susceptible to smuggling activities; capital control circumvention; customs, excise and income tax evasion; and money laundering and terrorist financing operations. These crimes are not new. For financial sector regulators, however, legislation against financial abuse of formal and informal remittance systems is a relatively recent phenomenon. In drafting new international standards-registration, licensing, reporting and record-keeping requirements-financial authorities also need to consider the settlement process between Hawala operators and the economic and regulatory implications of Hawala-type systems.

\section{In-Kind Remittances}

In-kind remittances take place through the provision of goods or services in one country, while the payment is made in another country. The tourism business, for example, lends itself readily for this sort of practice. A travel agent may send groups to Sri Lanka and collect full payment from them in Europe. In Sri Lanka, an associate will cover all local expenses of the group and receive payment in an account maintained overseas.

Many expatriates plan to return and retire in their homeland. Paving the way for return often means building a house. A local company may provide the construction work for the expatriate and receive payment in an overseas account. In Sri Lanka, for example, the real estate market has provided opportunities for such transactions, as expatriates wish to buy or sell property at home without disclosing the true price to the authorities. Balances between the real and declared price are settled through middlemen and payments outside the home country.

In-kind remittances pose an important measurement challenge. Large volumes of durable goods or valuable commodities - such as gold or gem stones-are hauled back to emigrants' home countries upon their return. Sometimes the value of these goods is counted as "official remittances," but sometimes it is not. Whether remittances are in the form of funds or value should not obscure the similar functions they perform or the effects they can have on regional economies. In Sri Lanka, initiatives are underway to mitigate the inefficiencies that arise from in-kind remittances. One of these initiatives is to allow the duty-free import quota to be used in special duty-free shops in Sri Lanka upon return from working abroad.

\section{Public and Private Sector Options for Enhancing the Use of Formal Remittance Systems}

There are different ways through which governments around the world have tried to encourage the use of formal remittance services, but for the most part, legal remittance requirement policies bave not been effective (see Annex 1 for regional perspective). India, for example, has enacted legislation banning the use of informal channels. In the Philippines, minimum remittance requirements (50 percent to 80 percent depending on the profession) were introduced in 1982, but the law soon became inactive because of implementation difficulties. Attempts in Pakistan, Thailand, and 
Bangladesh to introduce mandatory remittance limits have experienced similar fates (Puri and Ritzema, 1999).

The Republic of Korea has been more successful with mandatory remittance limits. The government mandated that at least 80 percent of the earnings of migrant workers be remitted through the Korean banking system. Available estimates indicate that the average formal remittance ratio of Korean workers (about 90 percent) usually exceeds the minimum legal limit. Puri and Ritzema (1999) observes that success in Korea is attributable to its unique migrant labor employment system in which almost all Korean migrant workers are employed directly by Korean companies involved in construction projects in the Middle East. ${ }^{14}$ The Korean corporations deposit their employees' salaries in foreign currency accounts in Korean banks. This approach ensures a higher remittance rate and promotes savings by workers in general.

By contrast, a large number of workers from Sri Lanka find employment overseas through independent recruitment agencies and other "unofficial" channels. A legal remittance requirement policy is therefore unlikely to not feasible. It might only succeed in the rare situation where the authorities have direct control over the entire process of labor migration.

Instead, it is recommended that reform efforts in Sri Lanka are invested in enbancing the quality of the outreach and quality of the formal financial sector. Lessons learned from other economies, such as Mexico which has a large migrant population, suggest that in order to compete with informal service providers the formal sector should consider the following: greater investment in remittance technology; sharing electronic payments systems platforms; creating payments systems linkages with non-bank-financial institutions; negotiating bilateral financial initiatives with remittance source countries; and promoting more financial education of migrant workers (Hernandez-Coss 2005).

\section{Greater Investment into Remittance Technology}

Overall, there is still a substantial amount of remittances going through the informal sector to residents in Sri Lanka. Although the costs of formal remittances to Sri Lanka are falling, informal channels continue to maintain a competitive hold on the market. In part, because as it is common with every bazaar in South Asia, the final quotation for an informal transaction depends on the negotiating skills of both parties and their understanding of how the market operates. Some informal remitters quote a flat fee of 2 percent on international transactions. Yet this is usually only a starting point for discussion. Discounts and premiums are offered and charged depending on the transaction volume, the relationship between the client and the remitter, the currency of exchange, and the destination of the funds.

On the other hand, the formal financial sector still incurs higher transaction costs than the informal sector. The vast bank branch network is largely suboptimal with respect to handling US\$ 100 in remittances for the average migrant. Formal remittance services in Sri Lanka largely rely on paper based instruments (bank drafts) and telegraphic money transfers that when processed through the bank feature relatively long processing time -- up to 21 business days for drafts and 48 hours for telegraphic transfers (Table 5). The charges levied for the use of 
each instrument depend upon staff and communication costs. Because of high SWIFT charges, the cost of a telegraphic transfer is higher than a draft or check (Table 6) and even more when compared to informal remittance channels such as Hawalla.

Table 5 Cost of Remitting Money To Sri Lanka (2005)

\begin{tabular}{lcccl}
\hline \multicolumn{1}{c}{ Country } & Currency & $\begin{array}{c}\text { Telegraphic } \\
\text { Transfer }\end{array}$ & $\begin{array}{c}\text { Draftl } \\
\text { Check }\end{array}$ & E-Remittance \\
\hline United Arab & Diram & $8-10$ & $3-5$ & $10-15$ \\
Emirates & & & & \\
(exchange houses) & & & & \\
USA (banks) & USD & $30-50$ & 25 & $10-62$ (for USD 100-500 remittance) \\
UK(banks) & GBP & 27.50 & 22.50 & $7-11$ (for GBP 100-500 remittance) \\
Other European & Euro & $10-75$ & 25 & $7-11$ (for Euro 100-500 remittance) \\
Union (banks) & & & & \\
\hline
\end{tabular}

Source: Central Bank of Sri Lanka (2005)

The use of bank drafts for remittances is bighly inefficient. Overseas remittance companies issue drafts on Sri Lankan banks, which the remitter mails to the recipient through the postal system. When the recipient receives the draft, he or she presents it to a bank branch. The branch presents the draft to the bank's main office for validation. When validated, the recipient's account is credited or cash paid over the counter. Remitting money using bank drafts presents several challenges. Drafts may be lost in the mail and may be forged. In Colombo, banks will deliver the cash for remittances to the home of beneficiaries without surcharge. This is not the case in the countryside where the beneficiary will have to visit the nearest branch once, in some cases twice to obtain cash. The settlement time is long because of the large part of manual work and transportation involved in processing the remittance. Although inexpensive to the remitter, the service level is inferior to what informal operators can provide and to what formal systems in developed remittance markets offer. The long transfer time may encourage recipients to relieve liquidity constraints through borrowing money at high interest rates from informal lenders.

There are also electronic fund transfers available to Sri Lankan migrants, but they are generally more expensive. International Money transfer businesses (MTBs) remit through commercial banks. Furthermore, commercial banks have entered into partnerships with exchange houses and overseas banks in setting up electronic infrastructures that allow remittance instructions from the overseas partner to initiate a credit to the recipient's account. Overseas workers are in some cases able to initiate transfers using the internet. Such transfers, provided the branch where the recipient is banked is on-line with the main office, can take place within a day.

In order to compete with the informal providers, the formal operators must lower transaction costs and improve the speed and distribution reach of their services. Banks must expand their international electronic transfers to rural areas. Branches must be connected to electronic payments 
processing so that recipients in remote areas can receive timely transfers. The banks could also move their services closer to the recipient, through couriers or partnerships with other agents. To improve service, a few private banks have opened branches in migrantdestination countries, and these branches have been able to attract new clients interested in remitting their earnings. Domestically, banks in Sri Lanka are starting to invest heavily into payments system technology. The use of credit cards, debit cards, and the installation of automated teller machines (ATMs) is on the increase (Table 6). In 2004, there were about 40 ATMs per 1 million inhabitants. Although public banks dominate the banking system, most ATMs are owned by private commercial banks (68 percent at the end of 2003).

Table 6 Total Branches of Commercial and Specialized Banks and Post

\begin{tabular}{lc}
\multicolumn{2}{c}{ Offices (2004) } \\
\hline \multicolumn{1}{c}{ Institution } & Number of Branches \\
\hline Public commercial banks & $618^{\star}$ \\
Private commercial banks & $756^{\star}$ \\
Specialized banks & 66 \\
Rural development banks & 196 \\
National Savings Bank & 112 \\
Post offices & $4647^{\star \star}$ \\
\hline
\end{tabular}

*Excludes pawning centers (188) and student savings centers (328)

**Includes agency and sub-post offices but excludes estate sub-post offices

Source: CBSL Payments Bulletin 2004

Hitherto, however, most banks have been investing in proprietary IT platforms for their payments systems with suboptimal gains for the remittance business. There is very limited outsourcing or sharing of domestic branch networks. Few banks have all branches "on-line" in a network. Paper-based processing of basic transactions has remained a predominant feature in branches and their head offices. Fortunately, this is changing. In 2004, close to 92 percent of ATMs in Sri Lanka were open-access, i.e., they could be used by the holder of an ATM card issued by a bank other than the bank that owned the ATM. But more can be done.

Like in many other Asian countries, it is unlikely that these electronic networks will reach out in the short or medium term to the poor and the rural areas. This is not only based on the limited density of the ATM network and their location (mainly in urban and commercial shopping areas). For the banks, ATMs require relatively high initial investments that will have to be recovered from the client operations. Hence, banks are likely to charge fees for cards and electronic transactions creating a threshold for low income users.

\section{Sharing Electronic Payments Systems Platforms}

To maximize, the remittance potential of the financial sector network, there needs to be a barmonization of the payments infrastructure across banks in the country. As in many developed countries, institutions in Sri Lanka should share their infrastructure platforms and compete on service. For a long time, for example, only a limited number of ATM transactions that 
required cross-institution clearing could be conducted. Electronic instruments offer a superior service, but in order to provide the best value to the user, such remittance instruments require that payments be processed electronically to the disbursing branches and that interbranch and interbank networks be connected electronically. In Sri Lanka, the lack of electronic interconnectivity between banks and many bank branches means that the recipient may not be able to receive the remittance at a bank branch. Indeed, Sri Lanka's branch network is not fully maximized (Table 6).

A notable example of the efficient sharing of an electronics platform (not only within one country but across an international border) is the Federal Reserve Automated Clearing House (FedACH) International (Box 2). The service is economical because it connects the existing payments infrastructure in both countries.

Hernandez-Coss (2005) rightly comments that it is too soon to know the impact that FedACH will have on the U.S.-Mexico remittances market. However, for smaller banks that do not have the capital to invest in their own systems networks, it presents an opportunity to become full participants in the market. In the case of the largest banks that have developed their own systems, the time required for a transaction through FedACH may be too slow compared to that required to complete an operation through their own system. One notable aspect of the Mexican Service is that it publishes the foreign exchange rate and spread on website, including an archive of previous rates, thereby adding an important element of market transparency not present in most other services. 


\section{Box 2. United States-Mexico. Federal Reserve Clearing House (FedACH) International}

A potentially significant addition to the remittances market between the United States (US) and Mexico is the FedACH International Mexico Service. FedACH provides a "public highway" for bulk transactions between banks in the US and Mexico. This clearinghouse is operated by the Federal Reserve System and the Central Bank of Mexico and reaches every bank in both countries as potential points of payment origination and receipt. Currently, this system works only from the United States to Mexico. Operators, however, plan to have the system working also in the direction of Mexico to the United States sometime in 2005. The cost to banks for using the FedACH system is estimated at around US\$ 0.67 per transaction. One of FedACH's limitations is that it operates only from account to account, as opposed to "cash to cash."

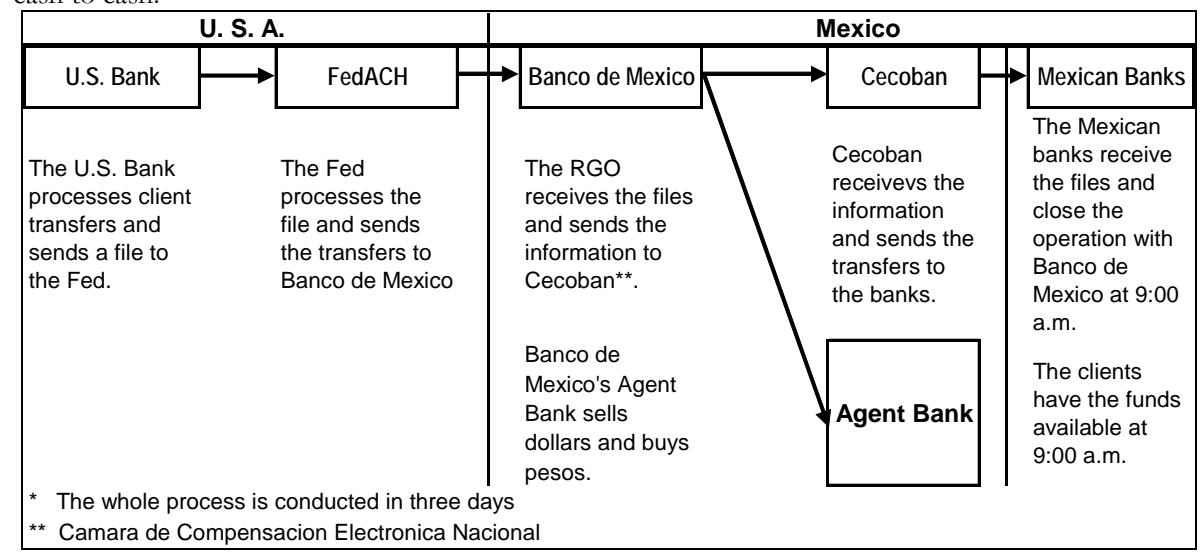

Source: Hernadez-Coss (2005)

There are several advantages to shared payments systems platforms. They can reduce the cost of remittances. Currently, major transfer agents and banks use their own (costly) proprietary systems to send remittances. If funds were channeled through a single low-value payment system, the cost per transaction could drop. Furthermore, the network effects of shared systems could provide easier access to disbursement points for the remittance recipients. One option for consideration is to allow post office branches to engage in payments by connecting post offices to an open network through which payments can be made and received. The ability to receive remittances from any bank through the post office has the potential of greatly increasing the value proposition to the remittance recipient. In addition, directing remittance payments through a broader electronic infrastructure is likely to reduce the cash-dependency of local payments. It would help pave the way for increased penetration of electronic payment instruments, such as credit and debit cards, which again would prepare the recipients of remittances for future cost-reducing innovations, such as card to card remittances.

The national IT platform that will soon be completed by Lanka Clear will also open new opportunities for expanding interconnectivity among banks. Lanka Clear's Check Imaging and Truncation System will involve connections with 11 regional IT clearing centers..$^{15}$ Once tested and operational, this electronic platform could be made available to commercial banks for a fee avoiding unnecessary and costly duplication of proprietary systems. 


\section{Creating Payments Systems Linkages with Non-Bank Financial Institutions}

In order to increase the speed with which remittances are channeled through the formal sector, banks need to explore greater linkages with non-bank financial institutions. Speed is a critical consideration. With self-carried, courier and Hawala deliveries, funds are available immediately, whereas some formal alternatives may take many days. Discussions in Sri Lanka suggest that on average 7-8 days is required to clear a draft made on a bank, although this varies widely among the banks, depending on their risk-taking policies and the level of technology. The timing also depends on the location of the branches, which the clearing period becoming significantly longer for remote areas. With informal transfers, confirmation and payment can be instantaneous, and the entire transaction can be concluded in minutes. Commonly 24 hours are required for transfers. Slightly more time is usually required for payments in the more remote regions or villages where the money exchange dealer has no local office or representative.

Sri Lanka can further reduce the cost of remittances by increasing rural access to banking services through partnerships with nongovernmental organizations and microfinance institutions. Such institutions may in particular be able to leverage remittance receipts to increase financial literacy and, if connected to payment networks, promote the use of technology in financial retail services. Such efforts should not be hindered by the lack of network effects due to an excess of proprietary systems. This can only successfully be achieved with financially sound microfinance institutions.

As a whole, Sri Lanka's 6000 microfinance (MF) points of contact, nearly 4650 post offices, 1374 bank branches, around 800 ATMs, and 112 NSB branches constitute a dense structure with a potential for very high electronic financial services penetration with providers focusing on services rather than infrastructure (Table 6). Looked upon as separate networks, however, such benefits will not be realized. In countries like Mexico, for example, remittances are delivered to recipients through a variety of outlets: banks, microfinance institutions, department stores, small neighborhood stores, telegraph offices, exchange houses, and post offices. In Sri Lanka, some of the better managed and financially more stable micro-finance institutions could potentially be a link for channeling remittances to rural communities. In most cases, this could still involve some investments in information technology and improvements in financial management systems.

An even larger network with tremendous potential for supporting the remittance industry is the Sri Lanka Post branch network of nearly 4650 post offices. Sri Lanka Post has a long tradition in providing financial services, mainly payments and savings, and these services constitute a substantial share of the workflow of the post offices (See Section V). At least two private commercial banks have expressed an interest in expanding the flow of payments through the postal network, a strategy that could enhance their outreach in a cost-effective manner. Sri Lanka Post is not connected to the Automated Clearing House (Lanka Clear), but efforts to increase its remittance capacity are under consideration. As part of the e-Sri Lanka program, Sri Lanka Post has recently launched e-money orders. Initially, the e-money order has been developed as an on-line payments instrument to support e-commerce transactions for those who do not have a 
credit card. The application of the e-money order, however, could be expanded to an on-line payments instrument for individuals.

Connecting the postal network to other postal and international payments networks (e.g., Eurogiro) would help to improve coverage and service. Eurogiro remittance products are delivered within two working days at a relatively low, fixed sender fee (US\$ 5-8). Through a Eurogiro connection, Sri Lankan migrants in e.g. Italy, Greece, Canada, Germany and Switzerland can use the local postal network and several local banks abroad to send money home. Several of the major Sri Lankan banks also envisage a role for the postal network to support the "last mile" delivery of cash for their remittance products by linking the postal network with the banks' processing center. Although the role of the postal network in domestic money transfers and migrant remittances is limited, there are untapped opportunities to expand these services by connecting the postal network with the local payments systems and international remittances networks.

\section{Negotiating Bilateral Financial Initiatives}

Bilateral initiatives between remitting and recipient countries can play an important role in enhancing the usage of formal remittance channels. The US-Mexico Partnership for Prosperity, a private-public alliance launched in September 2001, is perhaps the best example for Sri Lanka to emulate with its important remittance source countries. Recognizing the need for cooperative measures to manage the flow of remittances, the U.S. and Mexico have worked together to improve money transfer systems. Their agreements represent initial attempts to streamline the remittance process and to enhance the productive use of remitted funds.

The alliance has set out an action plan to promote economic development in the poorer regions of Mexico. Although the partnership is dealing with several important bilateral development issues, remittances is the area that has received the most attention. In the remittances area, the goal of the agreement is twofold: first, to reduce the cost of transactions; and second, to facilitate the transformation of remittances into productive activities, generating access to more integrated financial services. Partly due to the alliance described above and other initiatives referred to in this section, there has been a dramatic decline in the transfer costs between the two countries over the past eight years.

Supporting connectivity between domestic institutions and cross-border payments systems has the potential of providing low-cost, safe, and efficient remittance transfers. Such initiatives will need to be taken in cooperation with the remittance-sending countries, as the price to the sender depends on policies and connectivity in the sending country. Initial measures are being taken to connect the postal network with foreign postal networks.

\section{Financial Education and Consumer Protection}

There is evidence that Sri Lankan migrants do not have the knowledge level necessary to make informed choices among remittance alternatives. Despite an unusually high literacy rate for a developing country, these workers are, at first, quite oblivious to the realm of financial 
products and services available to them. The banking industry as a whole continues to offer a wide spectrum of services that enables migrants to better manage their savings but the country still lacks a cohesive strategy in educating this vital sector. ${ }^{16}$

Financial education is important for several reasons. First, it can help migrants overcome some of the misperceptions and social conditioning regarding formal financing institutions. Second, allowing the various providers of remittance services to inform migrants prior to departure, while disclosing all costs and benefits associated with their services, will encourage migrants to direct remittances to the most efficient providers, and as such create incentives for all remittance providers to enhance their services. Unskilled migrants are unfamiliar with the range of financial products and services available to them. The banking industry as a whole continues to offer a wide spectrum of services that enables migrants to better manage their assets but the country still lacks a cohesive strategy in educating this vital sector. Availability of information on providers and their services will encourage users to channel remittances to the most efficient providers and motivate competition in the remittance market with subsequent in services. In the past, the SLBFE has limited information to services offered by state commercial banks. Third, informing about the benefits of holding accounts and using financial products such as loans, deposits, and cashless bill payments, is key in moving from a cash-based society to a society based on electronic transactions, safe storage of value, and equal access to financial products. Such financial education should not be limited to migrants.

Stronger consumer protection will also encourage higher usage of formal networks. Remittance services should be covered by a well-founded consumer protection that ensures remedies for resolving disputes and a system for handling complaints. In particular, it is important that the recipients be aware of the total price paid for remittance services in relation to the original amount paid by the remitter to the sending agent. Furthermore, domestic organizations that enter into partnerships with overseas agents should ensure full disclosure of the price to the sender, or in cases where price components such as the exchange rate are not determined until after the transaction has been entered into, make the uncertainty of the pricing known to the sender beforehand.

\section{Conclusions}

Remittances to Sri Lanka have been growing steadily over the last few decades. The economic benefits of that growth are widely accepted-remittance income enables families to supplement their local income. To the extent remittances are transferred through formal networks, the government's balance of payments benefits from the increased foreignexchange reserves and the risks posed by informal networks are minimized. Equally important, the usage of formal financial institutions exposes migrants to a wide range of financial services (e.g., credit, savings, insurance) that can help them manage their savings and economic risks better.

In Sri Lanka, as in most other countries in the region, the majority of international remittances are channeled to rural areas. To maximize the development potential of remittances, however, it is important that efforts be made to enhance the service quality and rural outreach of the 
formal remittance infrastructure. This paper has discussed a number of options that the government may wish to consider to enhance the capacity of the public and private infrastructure to facilitate remittance flows.

In undertaking some or all of the efforts discussed in this paper, Sri Lanka is not alone. The importance of remittances and efforts to reduce the transaction costs for migrants is increasingly being recognized on an international level. Based on the increased worldwide focus on remittances, the World Bank and the Bank for International Settlements have convened a Task Force on General Principles for International Remittance Systems. These principles will support efforts to reduce impediments to access financial services in both remittances sending and recipient economies. Because of its experience with migrant worker remittances, the Central Bank of Sri Lanka was invited to join the Task Force, together with eight other central banks representing important sending and receiving countries. Through its participation, Sri Lanka is contributing to create a global understanding of the dynamics of the remittance sector. 


\section{Annex 1 Summary of Migrant Labor Remittances in the South Asia region ${ }^{17}$}

At a time that remittances are receiving renewed interest in international remittances four countries in the South Asia region stand out in terms of the volume of remittances they receive, the national policies in place to attract increased flows, and the efforts of formal financial institutions to deliver remittances faster and more cost effectively.

Bangladesh, India, Pakistan, and Sri Lanka have all experienced a sharp increase in remittances during the past decade. At the end of 2004, recorded remittances had increased to US $\$ 1.3$ billion (Table 1). Together with Bangladesh (US $\$ 3.4$ billion), India (US $\$ 23.0$ billion), and Pakistan (US $\$ 4.2$ billion), Sri Lanka was among the 20 largest recipients of remittances, collectively making the South Asia region the second largest regional recipient of remittances in the world after Latin America and the Caribbean.

Table 1 Estimates of Workers' Remittances Channeled through the Formal Financial Infrastructure (US\$ Billion)

\begin{tabular}{|c|c|c|c|c|c|c|c|}
\hline & 1999 & 2000 & 2001 & 2002 & 2003 & 2004 & $\begin{array}{l}2003 \\
\text { (per } \\
\text { capita } \\
\text { US\$) }\end{array}$ \\
\hline Total & 14.0 & 16.0 & 15.9 & 21.4 & 25.9 & 31.9 & \\
\hline Bangladesh & 1.8 & 2.0 & 2.1 & 2.8 & 3.2 & 3.4 & 23.2 \\
\hline India & 11.1 & 11.7 & 11.1 & 13.7 & 17.4 & 23.0 & 15.8 \\
\hline Pakistan & 0.1 & 1.1 & 1.5 & 3.6 & 4.0 & 4.2 & 27.0 \\
\hline \multirow[t]{2}{*}{ Sri Lanka } & & & 1.2 & & & 1.3 & 67.7 \\
\hline & 1.0 & 1.2 & & 1.3 & 1.3 & & \\
\hline
\end{tabular}

Source: World Bank, (2005)

That this increase in the quantity of remittances is taking place at a time of declining overseas development assistance (ODA) flows to the region is of additional importance. Interest in the development impact of remittances has increased because they continue to be the largest financial flow to the region after foreign direct investment.

The increase in remittance volumes has renewed academic and public policy interest in their potential to reduce poverty and economic vulnerability, improve family welfare, and stimulate local economic development in the face of much lower, sometimes temperamental, foreign direct investment flows.

To encourage higher flows into the region, governments in all four countries have taken active steps to support the migration of their nationals. The public infrastructure to support the search for employment abroad, the migration of successful applicants, and their subsequent stay is, in principal, in place. In all four countries, the public infrastructure includes emigration legislation, government ministries and departments, and a plethora of incentives for nonresident nationals. 
- Legislation: Legislation such as the Emigration Act of 1983 (India) and the Emigration Ordinance of 1979 (Pakistan) form the legal basis for today's migration practices and influence the ease and convenience of dealing with the resulting government ministries and departments. These provide the basis for the support governments provide to premigrants, migrants, and returnees.

- Government Departments: The Bureau of Manpower Employment and Training (Bangladesh), the Bureau of Emigration and Overseas Employment (Pakistan), and the Bureau of Foreign Employment (Sri Lanka) provide a range of pre- and postmigration services and facilities. For first-time migrants in particular, premigration training, visa application processing, and other services are highly prized. However, these bureaus have a mixed record in terms of their effectiveness and efficiency. The lack of resources limits their outreach and the types of services that they offer. As government institutions, perceptions of bureaucracies persist even where corrective actions have been undertaken.

- Incentives: The most notable government actions directed toward migrants have been the plethora of incentives that have been announced in successive budgets that specifically target migrants. These incentives include special access to the merit-based quota system assigned in all public professional colleges and universities; generous duty-free import limits for items of personal convenience; preferential allocation of investment opportunities such as initial public offerings to be subscribed in foreign currency; eligibility for special lotteries such as those for prime plots in public housing schemes at attractive prices; and tax exemptions.

While the presence of dedicated public institutions and government financial incentives aimed at facilitating and providing support for temporary migration and remittance inflows has helped the region address one of the basic challenges of facilitating large employment migration flows, and encouraging remittances back to the region, there remain more serious long term challenges.

First, despite this increasing interest, the specific development impact of remittances is still unclear and requires further research and debate. The following questions are particularly important: What proportion of remittance monies is spent on consumption versus investment? Does the proportion vary with the income and educational level of the remittance-receiving family? What kinds of productive investment activities are remittances spent on? How does this vary by setting (urban or rural), and by district, region, or country?

Second, the region has a large state bank branch networks with immense potential for a more effective and efficient remittance financial market. How can public policy encourage a more active use of the infrastructure without subsidizing private sector initiatives that might still have taken place even without the public intervention? Also, how, can the formal financial sector compete effectively with the trade-related informal remittance channels used by both legal and illegal migrants?

The recently published Migrant Labor Remittances in South Asia makes a start at addressing the questions raised above. Its authors, Samuel Munzele Maimbo, Richard Adams, Reena 
Aggarwal and Nikos Passas, emphasize that this publication is only a start, as many research challenges remain with respect to understanding the development impact of remittances, and identifying ways in which to strengthen the remittance infrastructure.

\section{Development Impact of Remittances}

Addressing the first set of questions is methodologically challenging because of three factors. The most important of these is that remittance income is fungible: that is, remittances can be spent on anything. This makes it very difficult to associate remittances with any specific changes in household patterns of consumption or investment. Second, remittances have multiple effects on the local economy. For example, an increase in the volume of remittances in a community may lead to higher spending on housing, which in turn helps to generate more income and employment opportunities for unskilled construction workers. Third, a robust theoretical and analytical framework for determining the development impact of remittances is largely absent. Because remittance research is often based on data collected at just one point in time, it is difficult to measure how remittances change patterns of investment over time.

This study analyzes the impact of international remittances on poverty using a growthpoverty model. This model, which has been used by a host of poverty researchers, ${ }^{18}$ assumes that economic growth —as measured by increases in mean per capita income-will reduce poverty.

The results are interesting. The analysis finds that, when the estimated values for unofficial remittances are added to official remittance figures, total remittances (official and unofficial) reduce the level of poverty in South Asia. On average, the point estimates for the poverty headcount measure suggest that a 10 percent increase in total remittances (official and unofficial) will lead to a 0.9 percent decline in the level of poverty in South Asia. This means that for a "representative" country where exactly one-half of the population lives below the poverty line, a 10 percent increase in total remittances (official and unofficial) will bring the proportion living in poverty down to about 0.48 percent.

\section{Remittance Infrastructure}

The second set of questions pose less methodological hurdles, and the authors comment on the state of the remittance capacity and potential of the state-owned banks, foreign commercial banks, money service businesses, post office networks and informal remittance systems

\section{State Banks}

The South Asian remittances market is unique for the presence of an extensive branch network of state commercial banks. That these banks have long dominated the official remittances business through monopolistic national foreign-currency legislation and large bank branch networks. Today, for example, India has over 32,000 rural commercial bank branches; Bangladesh has four nationalized banks with at least 3,346 branches in total; and Sri Lanka's largest state bank alone has 326 branches, 81 counter services, and 188 pawning 
centers. Physically, the infrastructure for an active far-reaching remittance network is already present. The challenge lies in making it more effective and efficient for that purpose.

Foreign Banks

Foreign banks have also noted the huge remittance potential in the region. Previously reluctant participants, they are slowly investing in this business, albeit largely for the higherincome migrants-doctors, accountants, lawyers, and other professionals. Foreign banks have hitherto largely been inhibited by their limited branch networks, which are primarily centered in major cities. They have been careful about heightened anti-money laundering and counter-terrorist financing standards, and concerned about the changing remittance business model. Profits from remittance transactions have been declining. The removal of foreign exchange controls, the competition from money transfer companies, and the pressure to make even speedier deliveries has reduced exchange gains, pushed down upfront commissions, and minimized the potential interest gains from cash floats.

\section{Local Banks}

It is largely the local banks that are taking the lead in the remittance service market. Investing heavily in various remittance application technologies—credit cards, debit cards, Internet banking, and telebanking - the local banks are surely changing the nature of the remittance market. The increase in the number of automated teller machines (ATMs) has been impressive. In Sri Lanka for example, the total number of ATMs operated by commercial banks increased to 705 at end of 2003 from 622 at end of 2002. In Pakistan one ATM network has over 392 ATMs in 26 cities; the other has 130. Yet the true potential for the ATMs to act as a remittance conduit or platform is yet to be realized. The majority of ATM transactions are only customers withdrawing cash from their own accounts. Only a limited number of transactions are customers using ATMs other than those installed by their own banks. Until this happens more frequently, the possibility of using the networks for remittance purposes will remain limited.

\section{Money Service Businesses}

The strongest remittance competition in the market comes from the emergence of licensed money service businesses (MSBs) — nonbank financial institutions that accept cash, checks, or other money instruments, or "stored value," in one location and pay the equivalent amount in another. Leading MSBs such as Western Union and Money Gram have extensive agent locations in the region that support their operations. However, Internet-based businesses such as e-exchange and Remit2India are having a positive impact on the way business is managed.

\section{Post Offices}

In the wake of declining traditional postal business, post offices in the region are exploring the possibility of participating in the remittance business more actively. Long used to delivering money orders to rural families, post offices are now investing in electronic money orders, partnering with money service businesses, and investing in Internet-based technology. The potential benefits for postal involvement are substantial. With 154,149 
postal offices and 554 sorting offices, India Post has the most extensive postal retail network in the world. Sri Lanka Post has 625 main post offices, 3,423 sub-post offices, and 632 agency post offices.

However, as long as the postal systems are plagued with operational losses, the absence of management information systems, limited access to funds for investing in technology, and negative publicity — such as stories of insufficient cash on hand and delays in effecting payment—client demand and usage will remain low. Reliability, credibility, and efficiency are essential ingredients to a remittance business.

\section{Informal Financial Institutions}

Informal remittance systems-courier services, in-kind remittances, and Hawala systemshave a long history in the region. Originally developed at a time when conventional banking instruments were either absent or weak, informal channels such as Hawala offered a speedy, low-cost, convenient, accessible, and (when necessary) anonymous option. Also referred to as hundi or chit, Hawala systems owe their popularity to the long history of trade in the region. Hundi, a form of bill of exchange or promissory note, was used in the region before the advent of modern banking. The interface between traders and Hawala dealers also owes much to the region's traditionally complex framework of regulating import and export transactions. Until very recently burdensome legislation regarding international payments, rebates, refunds, and other financial payments encouraged the use of informal alternatives.

Overall, migrants use informal systems for a variety of reasons, particularly their reliability, lower cost, speed, convenience and accessibility, and for some the anonymity that informality can provide users and recipients alike. Stongly based in trust and rooted in ageold cultural traditions, informal systems deliver cash much faster than conventional banking systems at a much more cost effective rate. Importantly, the convenience of door-to-door collection and delivery services is invaluable to migrants working long shifts and recipient families in communities with absent or weak formal financial services.

Unfortunately, the informal system's success-speedy transactions with minimal or no documentation-has also been its undoing. The anonymity associated with such transactions has long raised concern with law enforcement communities. This has led some countries to issue an outright ban on these systems; others have proceeded to or are considering issuing new regulations in an effort to improve the transparency of the sector.

\section{Conclusion and Recommendations}

The study concludes that remittances from migrant workers are increasingly important and are a stable source of external finance for countries in the South Asia region that can be sued for development-related activities by migrant family recipients. For its part, the public and private sector should invest in efforts aimed at enhancing the capacity of the extentive state and private bank network to deliver remittances more efficiently.

With an extensive state and private bank network already in the region, a key component of the requisite building blocks for an effective remittance industry is already in place. However, much more needs to be done to maximize the network's full potential, including: 
- Shared payments systems platforms: Greater investment in open architecture payments system information technology is required. Recipients should increasingly be able to receive remittances from any state or private bank branch or ATM machine, whether or not they hold an account with that institution. The potential for nonbank financial institutions, such as post office networks and money transfer businesses, to connect to banks' branches and technological advantages promises great potential for expedient, cost-effective remittance networks and services.

- Public-private partnerships: Strategic partnerships between the public and private sectors across infrastructure, products, and services are necessary for countries in the region that seek the types of gains attained elsewhere.

- Cross-selling: It is essential that, as the profitability of the conventional formal financial sector remittance business model continues to decline, formal financial institutions invest in cross-selling complementary financial services and products. Encouraging recipients to open and maintain bank accounts that might lead to short- and long-term auto and housing loans, for example, should be part of a business strategy for banks.

In the long run, strengthening the formal financial sector for remittance purposes will facilitate the move away from informal remittance systems, which, though beneficial to the direct users, may not have as effective an impact on the macro level as formal remittance transfers.

High transaction costs, long delays in transferring remittances, foreign currency controls, and overly bureaucratic polices and procedures for simple money transfers have no place in a vibrant and still-growing remittance industry.

\section{Notes/References:}

${ }^{1}$ Remittance trends in Sri Lanka are similar to worldwide trends. Globally, remittances remained the secondlargest financial flow to developing countries in 2003 after foreign direct investment, more than double the size of net official development assistance. Remittance volumes continue to increase, despite expectations to the contrary based on weak labor markets and the tightening of border controls in the industrial countries after the terrorist attacks of September 11, 2001.

${ }^{2}$ The relatively stable nature of remittances suggests that countries with access to significant remittance inflows may be less prone to damaging fluctuations, whether in output, consumption, or investment. In extreme cases, remittances might reduce the probability of financial crises. Such considerations are strengthened by the fact that remittances, unlike capital inflows, are unrequited transfers, which do not create future debt servicing or other obligations (IMF 2005).

${ }^{3}$ Based on the $2001 / 2003$ survey, total remittances constituted nearly 3 percent of income of the average household.

${ }^{4}$ The Middle East region has been the primary destination, having received almost 90 percent of total Sri Lankan contract workers. 
${ }^{5}$ As early as 1982, Sri Lanka was among the top 10 countries with the largest portion of national livings outside the country. Of a population of 17 million at the time, 1.5 million had left the country (The Economist, 1993:40). ${ }^{6}$ Research by Richard Adams suggests that if remittances are used mainly to finance basic consumption, they may have an effect on poverty even though their growth impact may be minimal: on average, a 2.5 percentage point increase in the remittances/GDP ratio is associated with less than a 0.5 percentage point decrease in the share of people living in poverty (IMF, 2005).

7 The Ministry of Employment and Labor and its implementing arm, the Sri Lanka Bureau of Foreign Employment (SLBFE), are directly active in the migration and remittances business. The ministry is responsible for formulating policies and monitoring the overall administration of foreign employment, as well as coordinating with relevant state agencies. SLBFE implements a wide range of workers' welfare programs, both locally and in host countries that protect migrant workers during the entire migration process. SLBFE is responsible for monitoring the migration of individuals, the activities of employment agencies, and the promotion of foreign employment opportunities especially to the Arabian Gulf states to which the majority of unskilled workers emigrate.

8 Although this paper focuses on the financial benefits of remittances, it does so recognizing that labor migration is not without its negative social consequences. Before they leave Sri Lanka migrants may become involved in an illegal process of paying bribes to employment agencies, borrowing money from loan sharks and falsifying passports and travel documents. On arrival in the host country, tales of slavery, forced prostitution and inhumane treatment of female migrants abound. Often, there is nothing the worker can do except run away without her travel documents; after which, she may be picked up by the all too numerous prostitutions rings, or by law enforcement agencies and detained for long periods without legal recourse before being unceremoniously deported. Finally, on her return to Sri Lanka, the migrant may further face stigmatization as communities assume they led a promiscuous life abroad. Others find that their husbands have taken on mistresses, become alcoholics, and not tended to the families education, housing or medical needs (Abu-Habib, 1998, 53-55; and The Economist, 1993:40).

${ }^{9}$ While achievements have been made in Sri Lanka with respect to access to financial services, households in rural areas still have less access to formal financial services in general and remittance products in particular. Many banks claim to be present in every corner of the country, but large regional disparities exist in the distribution of financial services (Figures 1.6-1.7). These differences exist both in terms of transactions and in branch density, with clients in economically weaker regions having a disproportionately lower level of financial services.

${ }^{10}$ These figures exclude pawning centers (188) and student savings centers (328).

11 This includes drafts/checks drawn on banks of which the settlement of foreign currency is funded by NBMTSPs in Blocked accounts and drafts/checks drawn on non-resident rupee accounts and non-resident foreign currency accounts funded and maintained by NBMTSPs with authorized and registered dealers in Sri Lanka of which payments are made to beneficiaries by debiting such accounts.

${ }^{12}$ State banks have taken the initiative to encourage savings with enhanced interest rates for foreign currency accounts and other loan benefits (Malsiri D. and R. Jayasundere, 1999). The People's Bank offers two lowinterest loan schemes. One, called Siyatha, offers credit at an interest rate of 16 percent to sudden returnees from war-torn Gulf countries of up to Rs. 250,000 for purchasing land, building a house or for investing in self-employment activities. The second scheme, called Videshika, provides credit to all migrant workers to meet costs of employment or to purchase assets. This scheme also offers a credit ceiling of Rs. 250,000 at an interest rate of 16 percent. Both credit schemes are subsidized by the SLBFE with the SLBFE paying 9 percent of the interest on Siyatha loans and 7 percent on Videshika loans. The Bank of Ceylon offers two credit programs to migrant workers, one known as the Ransaviya $I$ to set up self-employment projects at an interest rate of 16 percent - of which the SLBFE pays 8 percent - and Ransaviya II where Non-Resident Foreign Currency account holders are able to obtain credit to improve their standard of living at an interest rate of 16 percent - of which the SLBFE pays 7 percent. 
${ }^{13}$ Informal transfers to the region are said to be significant, particularly from countries where there are large groups of illegal migrants, and countries where the formal banking sector is weak or lacks relations with a particular country. Some observers note that many South Asians shifted their savings and investments from the West back to South Asia-through formal and informal channels-because of uncertainties and anxieties generated by asset seizures and other counterterrorist finance measures introduced after September 11, 2001.

14 The government plays an active role in the process by directly assisting companies to win contracts, as part of its export promotion strategy.

${ }^{15}$ Lanka Clear is an organization jointly owned by the Central Bank (20 percent of capital), state banks (28 percent), and local private and foreign commercial banks (52 percent). It operates the check clearing system, the SLIPs and the US dollar cheque clearing systems.

16 Abeywickrema, C. (2004).

${ }^{17}$ See Maimbo, S., Adams, R., Aggarwal, R. and Passas, N., (2005). Migrant Labor Remittances in South Asia. Directions in Development. Washington D.C: World Bank. 